\section{Shelf life of anchovy products (Engraulis encrasicolus): evaluation of sensory, microbiological and chemical properties}

\author{
Andrea Ariano, ${ }^{1}$ Luigi Scarano, ${ }^{1}$ Amalia \\ Mormile, ${ }^{1}$ Maria Barile, ${ }^{1}$ Giuseppe Palma, ${ }^{2}$ \\ Nicoletta Murru' \\ 'Dipartimento di Medicina Veterinaria e \\ Produzioni animali, Università degli Studi \\ di Napoli Federico II; ${ }^{2}$ Federpesca, Roma, \\ Italy
}

\section{Abstract}

Fishery products have always been an important food in Italy. In the past, increased consumption was mainly due to the good quality of the products, easiness of use and their beneficial effects on health. Recently, owing to the national financial crisis, there has been a decline in the consumption of fish. In fact, in 2013, according to data from ISMEA, the consumption of fresh fish suffered a sharp contraction (-5\%). This decline also concerns anchovy (Engraulis encrasicolus). This species, partly because of its low price, is a mainstay of traditional Italian food. The aim of this study was to evaluate sensorial, chemical and microbiological properties of anchovy-based (Engraulis encrasicolus) products during storage at 4 and $-20^{\circ} \mathrm{C}$. Fresh anchovies, obtained from the wholesale fish market of Pozzuoli (Southern Italy) were cut into small pieces and hand-prepared using bread, eggs, cheese and lemon juice. Samples were analysed after $0,2,4,6$ and 8 days of storage at $4^{\circ} \mathrm{C}$. An aliquot was quickly frozen and analysed after 34 days at $-20^{\circ} \mathrm{C}$. Sensory assessment, microbiological (specific spoilage organisms, Listeria spp. and Salmonella spp.) and chemical (histamine, total volatile basic nitrogen, trimethylamine, thiobarbituric acid, $\mathrm{pH}$ and $\mathrm{a}_{\mathrm{w}}$ ) analyses were performed. Results showed that the shelf life of anchovy products was less than 5 days for the samples stored at $4^{\circ} \mathrm{C}$. At $-20^{\circ} \mathrm{C}$, all anchovies preparations showed good sensory, microbiological and chemical properties for 34 days.

\section{Introduction}

Fishery products have always been an important food In Italy. In the past, increased consumption was mainly due to the good quality of the products, ease of use and their beneficial effects on health.

Currently, there is a strongly decline in consumption of fish mainly related to the financial crisis so much so that in 2013 the consumption of fresh fish by Italian people suffered a sharp decline (-5\%) (ISMEA, 2013). This negative trend also regards the anchovy (Engraulis encrasicolus) market. This fish species has always been a part of traditional, poor cuisine because, despite its status as the most prized of small fish, it actually costs little. Although the anchovy market is historically linked to the sale of fresh produce and produce preserved in salt and oil, it could be important to diversify this by developing new kind of products. The aim of this trial was to assess the shelf-life of anchovy (Engraulis encrasilocus) meatballs stored at $4^{\circ} \mathrm{C}$ for 8 days and at $-20^{\circ} \mathrm{C}$ for 1 month by evaluating their microbiological, chemical and sensorial features.

\section{Materials and Methods}

For the study, a batch of fishballs was made at the workshop at Pozzuoli fish market using anchovies (Engraulis encrasilocus) fished no more than $5 \mathrm{~h}$ before in the nearby Gulf. The fishballs, which were bigger than a walnut, were obtained by manually mixing anchovies (cut with scissors), bread, eggs, cheese and lemon juice and coating the same with bread crumbs at the end. Then, 8 meatballs at a time were packed in aluminum semi airtight containers covered with foil and stocked at $4^{\circ} \mathrm{C}$. One container was frozen and stored at $-20^{\circ} \mathrm{C}$ for more than a month. All the refrigerated samples and raw materials were submitted to sensorial, chemical and microbiological analyses after $0,2,6,8$ storage days. The frozen sample, on the other hand, was analysed after 34 days of storage. All the analyses were performed at a food inspection laboratory.

\section{Sensorial analyses}

All samples were subjected to sensorial analyses by a test panel of 5 qualified people who evaluated the colour, flavour, texture and the presence of liquid in the containers. Afterwards, the meatballs were cooked in hot oil as preparation for a taste test.

\section{Microbiological analyses}

For the microbiological analysis, 25 gr of sample were homogenised in $225 \mathrm{~mL}$ of (w/v) sterilised $0.2 \%$ peptone water at $45^{\circ} \mathrm{C}$ in a Stomacher Lab-Blender 400 (PBI Internatio nal, Milan, Italy) and consecutive ten-fold serial dilutions were made in sterilised $0.2 \%$ peptone water. Aerobic mesophilic counts
Correspondence: Dipartimento di Medicina Veterinaria e Produzioni animali, Università degli Studi di Napoli Federico II, via Federico Delpino 1, 80137 Napoli, Italy.

Tel. +39.081.2536084 - Fax: +39.081.458683.

E-mail: arianoandrea87@gmail.com

Key words: Engraulis encrasicolus, Fish preparations, Shelf life, SSOs, Histamine.

Received for publication: 27 May 2013.

Revision received: 27 July 2013.

Accepted for publication: 29 August 2013.

This work is licensed under a Creative Commons Attribution 3.0 License (by-nc 3.0).

(C) Copyright A. Ariano et al., 2014

Licensee PAGEPress, Italy

Italian Journal of Food Safety 2014; 3:1678

doi:10.4081/ijfs.2014.1678

(AMC) were enumerated on plate count agar (PCA; 0xoid, Milan, Italy) after $48 \mathrm{~h}$ and 15 days of aerobic incubation at 32 and $4{ }^{\circ} \mathrm{C}$, respectively, enterobacteriaceae on violet red bile glucose agar (VRBG; OXOID), using the pour-plate and overlay technique, after $48 \mathrm{~h}$ of incubation at $37^{\circ} \mathrm{C}$, Pseudomonas spp. on pseudomonas agar base+Pseudomonas $\mathrm{C}-\mathrm{N}$ C Supplement (OXOID) at $22^{\circ} \mathrm{Cx} 48 \mathrm{~h}$; Aeromonas spp. on Aeromonas Medium Base+Ampicilin Supplement (OXOID) at $30^{\circ} \mathrm{Cx} 48 \mathrm{~h}$, Brochothrix thermosphacta on SPAA Agar Base+STAA selective Supplement (OXOID) at $22^{\circ} \mathrm{C} \times 48 \mathrm{~h}$, Listeria spp. and Salmonella spp. according to ISO 6579:2008 (ISO, 2008) and ISO 11290-1:1996 (ISO, 1996), respectively. All analyses were performed in duplicate and the mean value of each count was expressed in Log cfu/g.

\section{Chemical analyses}

In all samples, $\mathrm{pH}$ (pH-meter FE20; Mettler, Toledo, Spain) were determined: $a_{w}$ (activity water, con HigroLab rotonic PBI), total volatile basic nitrogen (TVB-N) (Antonacopoulos and Vincke, 1989), trimethylamine nitrogen (TMA-N) (AOAC, 1984), Thiobarbituric acid (TBA) (Pearson, 1973), Histamine (Emborg and Dalgaard, 2006).

\section{Results}

\section{Sensorial analyses}

After 4 days of storage, anchovy fishballs stored at $4^{\circ} \mathrm{C}$ showed a lively and bright colour, a firm texture, had a pleasing smell and there was no liquid in the package. From the $6^{\text {th }}$ day of storage, they were grayish in colour, had a pungent odour, less firm texture and there was a turbid liquid in the package. 
On the $8^{\text {th }}$ storage day, a complete loss of freshness was observed. Regarding the taste test, the anchovy fishballs were acceptable up to the $4^{\text {th }}$ day of storage. After thawing, the frozen samples showed sensorial features similar to those of the refrigerated fishballs on the first day of storage.

\section{Microbiological analyses}

In the refrigerated samples, TVC at 32 and $4^{\circ} \mathrm{C}$, and enterobacteriaceae after 8 days of storage reached values of $8.63,6.23$ and 4.89 $\log$ CFU/g, respectively (Figure 1). Aeromonas spp. and Pseudomonas spp. increased gradually and constantly during storage (Figure 2).

In the frozen sample, TVC at $32^{\circ} \mathrm{C}$ and enterobacteriaceae showed lower values like those registered at the beginning of storage. On the contrary, TVC at $4{ }^{\circ} \mathrm{C}$ increased by 4.59 $\log \mathrm{CFU} / \mathrm{g}$ compared to the values of raw material (Figure 1). Aeromonas spp. and Pseudomonas spp. were absent in the frozen sample (Figure 2). Brochothrix thermosphacta, Listeria spp. and Salmonella spp.

All bacteria results are shown in Figures 1 and 2.

\section{Chemical analyses}

TVB-N and TMA reached 12.14 and 34.42 $\mathrm{mg} / 100 \mathrm{gr}$ on the $6^{\text {th }}$ day, 22.14 and $35.42 / 100 \mathrm{gr}$ after 8 days of storage at $4^{\circ} \mathrm{C}$ (Figure 3 ). In the chilled product, on $34^{\text {th }}$ day values of 20.45 and $4.8 \mathrm{mg} / 100 \mathrm{gr}$ for TVB-N and TMA respectively were revealed. From an initial value of 5 $\mathrm{mg} / 100 \mathrm{gr}$, histamine increased during refrigerated storage up to $20 \mathrm{mg} / 100 \mathrm{~g}$ on $8^{\text {th }}$ day (Figure 3). As regards TBA, concentrations of malonaldehyde of $0.98 \mathrm{mg} / \mathrm{Kg}$ in the refrigerated samples on $8^{\text {th }}$ day and of $0.16 \mathrm{mg} / \mathrm{Kg}$ in the chilled sample were detected. In all samples, $\mathrm{pH}$ was 6.17 on first day and then decreased and showed the mean value of 5.64 until the end of storage. $A_{w}$ showed the mean value of 0.95 during entire storage in all samples.

Chemical results are shown in Figure 3.

\section{Discussion and Conclusions}

Pseudomonas spp. and Aeromonas spp. are widely recognised as specific spoilage organisms (SSOs) of fish products (Gram and Huss, 1996; Gram et al., 2002; Dalgaard et al., 1995) deteriorating them when exceeding the value of $5 \times 10^{5} \mathrm{UFC} / \mathrm{g}$ (ICMSF, 1986) In this trial, these microorganisms showed a low charge in the raw material. From the $5^{\text {th }}$ day, the gradual increase of TVC at 32 and $4{ }^{\circ} \mathrm{C}$, Aeromonas spp. and Pseudomonas spp. was accompanied by a gradual loss in freshness (Alasalvar et al., 2001).

TVB-N and TMA was higher than the limits of 35 and $20 \mathrm{mg} / 100 \mathrm{~g}$ in the refrigerated sam- ples on the $8^{\text {th }}$ day of storage. Histamine showed values lower than the limits of Reg. 2073/2005 (European Commission, 2005) until the end of storage. Regarding TBA, the concentration of malonaldehyde was always lower than the limit of $5 \mathrm{mg} / \mathrm{Kg}$ for products widely oxidised.

The frozen product had good sensorial, microbiological and chemical features after 34 days of storage at $-20^{\circ} \mathrm{C}$ thanks to the rapid reduction of the temperature and to early processing times after the capture.
Our results allow us to define a shelf life of 4 days for refrigerated anchovy meatballs and of 34 days for the chilled product.

The anchovy is a fish species which is still under appreciated despite its high nutritional value. The development of new anchovy preparations could promote the consumption of this fish species especially by particular categories of consumers such as the elderly and children. of course, in order to deliver a flawless product, it is necessary to start with fresh raw material and to respect the cold chain.

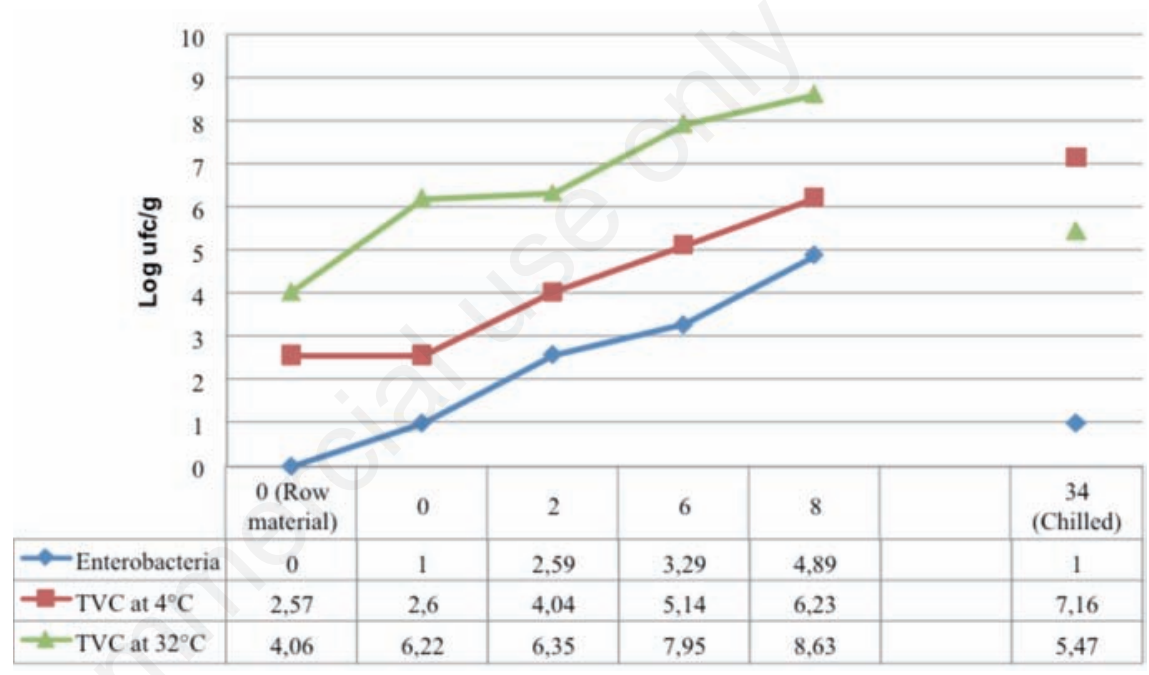

Figure 1. Average values of total viable count at 32 and $4^{\circ} \mathrm{C}$, and Enterobacteria in anchovy fishballs.

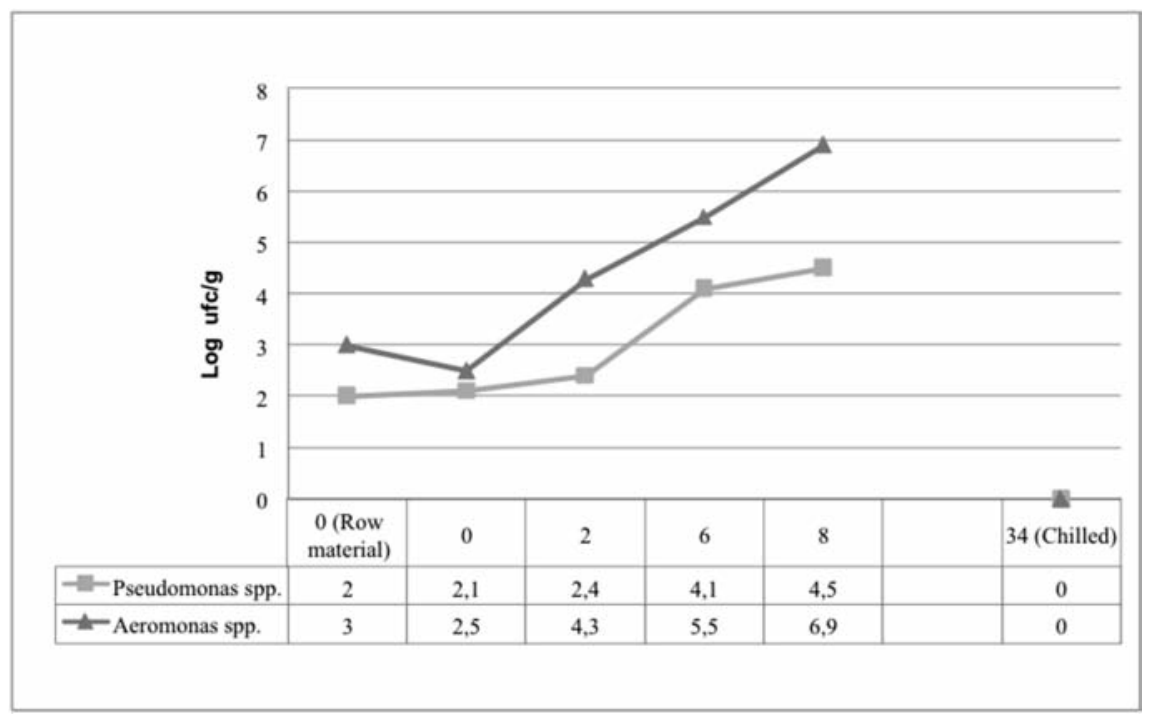

Figure 2. Average values of Aeromonas spp. and Pseudomonas spp. in anchovy fishballs. 


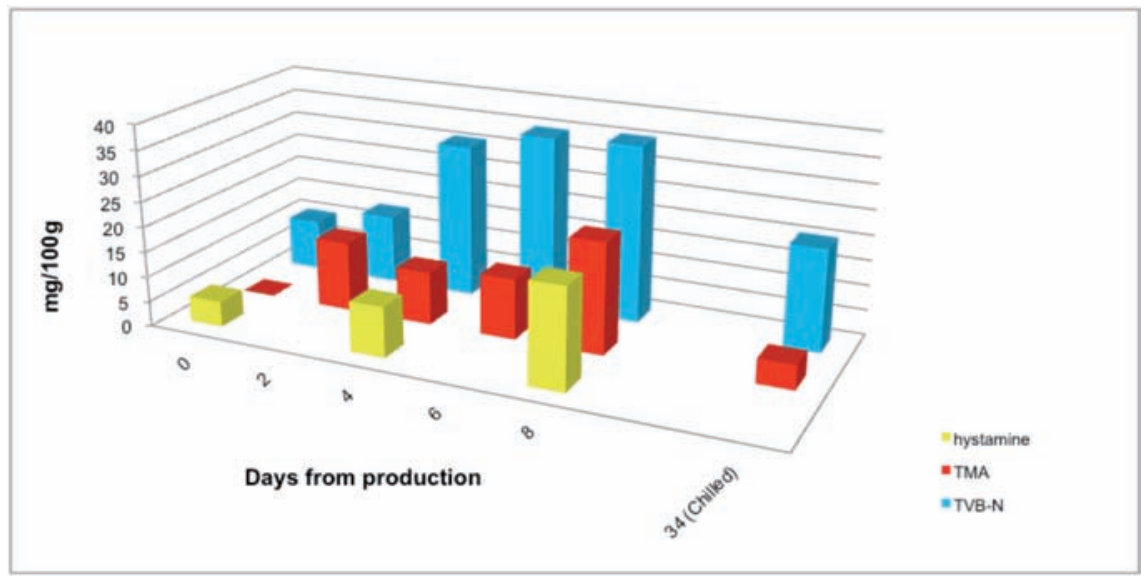

Figure 3. Average values of total volatile basic nitrogen, trimethylamine and hystamine in anchovy fishballs. the European Parliament and of the Council of 15 November 2005 on microbiological criteria for foodstuffs, 2073/2005/EC. In: Official Journal, L 338, $22 / 12 / 2002$.

Gram L, Huss HH, 1996. Microbiological spoilage of fish and fish products. Int $\mathbf{J}$ Food Microbiol 33:121-37.

Gram L, Ravn L, Rasch M, Bruhn JB, Christensen AB, Givskov M, 2002. Food spoilage: interactions between food spoilage bacteria. Int $\mathrm{J}$ Food Microbiol 78:79-97.

ICMSF, 1986. Microorganisms in foods 2. Sampling for microbical analysis: profiles and specific applications. 2nd ed. University of Toronto Press, Buffalo, NY.

ISMEA, 2013. Trend of consumption of fish in Italy. Istituto di servizi per il mercato agricolo alimentare ed., Rome.

ISO, 1996. Microbiology of food and animal feeding stuffs. Horizontal method for the detection and enumeration of Listeria monocytogenes. Part 1: detection method. ISO norm 11290-1:1996. International Organization for Standardization Publ., Geneva.

ISO, 2008. Microbiology of food and animal feeding stuffs. Horizontal method for the detection of Salmonella spp. ISO norm 6579:2008. International Organization for Standardization Publ., Geneva.

Pearson D, 1973. Laboratory techniques in food analysis. Butterworths, London. 